\title{
土地履歴の解釈にもとづく文化財としての文化的景観の捉え方の検討
}

\section{A study on cultural landscapes as cultural properties in terms of land history interpretation}

\author{
宮本 万理子* 横張 真* 渡辺 貴史** \\ Mariko MIYAMOTO Makoto YOKOHARI Takashi WATANABE
}

\begin{abstract}
This article proposed a new concept of cultural landscape as cultural properties. To accomplish this aim, two objectives were set. First, discourse of cultural landscape which effected on the category of cultural landscape defined by UNESCO was examined to make a new concept of cultural landscape as cultural properties. Second, a new concept of cultural landscape as cultural properties in terms of land history (historical process of interaction between landscape and society) interpretation was proposed based on the definition of cultural landscape defined by Wagner \& Mikesell. Furthermore, landscapes were categorized based on the existence of historical record such as historical maps and documents to trace land history. Based on this concept, four types of landscapes; (1) existence of maps / existence of documents, (2) existence of maps / absence of documents, (3) absence of maps / existence of maps, (4) absence of maps / absence of documents were categorized. From a planning viewpoint, (1) existence of maps / existence of documents was recognized as "cultural landscapes" in this research.
\end{abstract}

Keywords: cultural landscape as cultural properties, land history, interpretation キーワード：文化財としての文化的景観，土地履歴，解釈

\section{1. はじめに}

文化的景観（以下，UNESCO が定める文化的景観を CL と称 する）は，自然と人間との共同作品 1)であるとされる。この概念 は，文化財保護法の改正を背景に ${ }^{22}, 2005$ 年に文化庁により導入 された 3)。上記に加えて, 景観法 (2003), 歴史まちづくり法 (2008) の制定により，文化的景観（以下，文化庁が定める文化的景観を 文化的景観と称する）の保全に高い関心が集まっている ${ }^{3)} 5$ )。

従来, 文化財とは歴史・学術・芸術上価值の高いものとされて いる 2)。こうした概念にもとづく文化的景観とは，歴史・学術・ 芸術上価値の高い景観であり, 過去から現在にかけて形態が変化 することなく継続した景観である場合が多い6)。しかし，文化財 の意義が，過去の生活・生業を理解することにあるとすれば 2), 歴史・学術・芸術上価值の高い景観のうち, 過去から現在にかけ て景観が変化しながら継承された景観についても，文化財として の価值が認められる場合があると考えられる7)。

文化的景観の保全対象となる景観は，（i）それ自身で高い価值 を有するもの，（ii）他の記念物等の文化財の周辺に展開し，一体 の価值を有するもの，の 2 つに大別されるとされる 6)。こうした 景観は，記念物等の文化財が含まれていることや，景観そのもの が文化財としての価值を特定しや寸いため, 保全の対象にしやす い。しかし，上記以外の景観は，景観そのものの変化が著しい場 合が多いことや，記念物等の文化財を含まないことから，保全対 象として特定しづらい。このように保全される景観が限られるの は，文化的景観であるか娝かを特定する選定基準が限定的だから と考えられる 8)。従って，今後は(i) (ii) 以外の景観を捉える概念 の検討が必要である9

以上より，本研究は，文化的景観の概念を拡張するべく，(i) (ii)以外の景観のうち, 土地履歴の解釈にもとづき特定された景観 を『文化的景観』と定義し，『文化的景観』に承認される景観を特
定する概念を検討した。具体的には，まず，文化庁が文化的景観 を定めるにあたって参照したとされる UNESCO の CL の成立に 影響を与えた言説を整理し, 『文化的景観』の概念の構築に活用で きる言説を検討した。次に抽出された言説と既存の文化的景観を 選定する手法を参考に,『文化的景観』に承認される景観を特定す る概念を検討した。そして最後に, 先の概念を, 近世期に幕府直 轄の牧があり，『文化的景観』に承認できる景観が存在すると考え られる下総台地の初富地区 (千葉県鎌ヶ谷市) ・南増尾地区 (千葉 県柏市) ・ 芝崎地区 (千葉県流山市) ・ 中沢地区 (千葉県鎌ヶ谷市) に適用し，概念の妥当性を検証した。

\section{C Lの成立に影響を与えた言説の整理}

文化庁が文化的景観を定めるにあたっては, 1992 年 UNESCO による世界遺産条約の登録カテゴリーに追加された CL のカテゴ リーを参考としたとされている 1110)11)。そこで本章では, UNESCO の CL に関わるカテゴリーの成立に影響を与えた言説 を整理する。

世界遺産登録カテゴリーでは，CL は「自然と人間との共同作 品 (combined works of nature and man)」に相当するものであ るとされる 1)。さらには, CL を以下 3 つに分類している。第 1 は「意匠された景観 (landscape designed and created intentionally by man)」, 第 2 は「有機的に進化する景観 (organically evolved landscape)」, 第3は「関連する景観 (the associative cultural landscape)」である。さらに第 2 のカテゴリ 一は,「(i) 化石景観 (a relict (or fossil) landscape)」,「(ii) 継続 する景観 (a continuing landscape)」として 2 つのサブカテゴリ 一に細分される1)。

文化的景観を定めるに際しては, 第2のカテゴリーとされる「有 機的に進化する景観 (organically evolved landscape)」にもとづ き検討がなされ ${ }^{12)}$ ，(1)既にある「記念物」の制度とは別に，面的

\footnotetext{
*東京大学大学院新領域創成科学研究科埼長崎大学大学院水産・環境科学総合研究科
} 


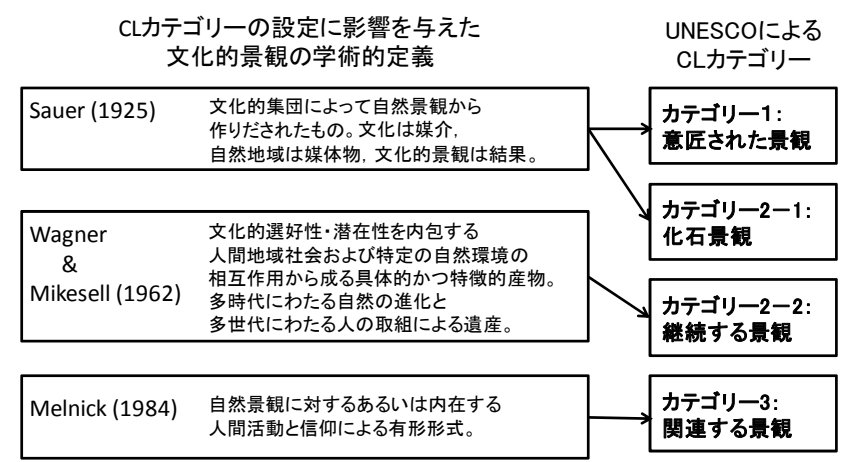

\section{図-1 文化的景観の学術的背景と UNESCO の文化的景観カテゴリ一の関係性}

区域として設定すべきであること，(2)ある程度の施業形態の変更 も認めるべきであること，などが議論されている ${ }^{13)}$

これら 4 つのカテゴリーのうち「(ii) 継続する景観」は, 『文 化的景観』の概念を考える上で，もつとも重要なカテゴリーと考 えられる 14)。さてこれら 4 つのカテゴリーの成立に影響を与えた のは，どのような言説なのだろうか。

CL に関わる 4 つのカテゴリーは,「世界遺産条約のための作業 指針 (The Operational Guidelines for the Implementation of the World Heritage Convention)」（以下，作業指針とする）策定 に関与した学識者 (考古学, 歴史学, 地理学, ランドスケープエ コロジー, ランドスケープアーキテクチャーから成る学識経験者) および世界遺産センター，関連 NGO（ICOMOS（国際記念物遺 跡会議)，IUCN (国際自然保護連合), IFLA (国際造園家連盟) によって検討された 10)11)

このうち作業指針策定時に学識者の中心的役割を担った英国考 古学者である Fowler (2003)は, カテゴリー検討時に, 地理学者 による 3 つの “文化的景観”（以下，学識者による文化的景観を 総称して”文化的景観 “とする。）の定義を参照したとしている 10)。

第1は, Sauer (1925)によるものである。Sauer は, “文化的 景観”を「文化的集団によって自然景観から作りだされたもので ある」とし，「文化は媒介で，自然地域は媒体物であり，“文化的 景観” は結果である」と定義した ${ }^{15)}$ 。著者らは，同定義を，人が 形成した文化を通して自然に働きかけ，その結果，“文化的景観” が生成されると考えられるため, UNESCO の CL カテゴリーの 「意匠された景観」と「化石景観」に対応するものと解釈した。

第2は, Wagner \& Mikesell (1962)によるものである。Wagner \& Mikesell は, Sauer の概念を踏まえた上で 16)，“文化的景観” を「文化的選好性・潜在性を内包する人間地域社会および特定の 自然環境の相互関係から成る具体的かつ特徵的産物である。これ は多時代にわたる自然の進化と多世代にわたる人の取組による遺 産である」と定義した ${ }^{16)}$ 。著者らは，同定義を，人と自然の相互 関係の結果により “文化的景観”が生成されるとする点，経時的 に“文化的景観” は変容するとしている点から, UNESCO の CL カテゴリーの「継続する景観」に対応するものと解釈した。

第 3 は, Munjeri (2000) 17)によるものである。Munjeriは, 前 二者の定義が自然と人閒を切り離した欧州偏重の考え方とし ${ }^{10)}$, Melnick (1984) 18)を引用しつつ, “文化的景観”を「自然景観に対 するあるいは内在する人間活動と信仰による有形形式である」と 定義した ${ }^{17)}$ 。著者らは，同定義を，信仰を通して人が自然に内包 されるとすることから，UNESCO のCL カテゴリーの「関連す る景観」に対応するものと解釈した。

以上から，文化庁が文化的景観の概念を検討した時に参考にし た，世界遺産条約登録カテゴリーの CL に関わる 4 つのカテゴリ
一のうち，「継続する景観」が，『文化的景観』に類似する概念で あることが考察された。次に 4 つのカゴリーと世界遺産条約の 作業指針策定時に参考にした言説との対応関係を検討したところ， SauerのCLの定義は「意匠された景観」と「化石景観」に, Wagner \& Mikesellの定義は「継続する景観」に，Melnickの定義は「関 連する景観」に影響を与えていることが著者らにより解釈された (図一1)。なかでも，「継続する景観」に影響を与えた Wagner \& Mikesell による定義は, 「継続する景観」の定義と比べて，景観 と社会の相互関係から “文化的景観”が生成されるとする点にお いて明確な概念が提示されており，『文化的景観』に承認される景 観を特定する概念を考える上で，注目す心゙き概念であると考えら れた。そこで次節では, Wagner \& Mikesell の定義にもとづき,

『文化的景観』を特定する概念を検討することとする。

\section{3.『文化的景観』に承認される景観を特定する概念の検討} （1）『文化的景観』に承認される景観を特定する概念の設定

Wagner \& Mikesell の「文化的選好性・潜在性を内包する人間 地域社会」は「社会」に，「特定の自然環境」は自然的・人文的作

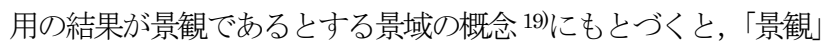
に置換できると考えられる。以上から，Wagner \& Mikesell の定 義にもとづくと『文化的景観』は, 過去から現在にわたる景観と 社会との相互作用から捉えられると考えられた。そこで本稿では, 過去から現在にわたる景観と社会との相互作用を土地履歴と定義 し，土地履歴から『文化的景観』を捉えることとした。

図-2 は, Wagner \& Mikesell の定義にもとづき著者らが作成 した土地履歴にもとづく『文化的景観』の概念図である。まず, 時代Tにおける景観（B）は，景観（A）と社会との相互作用の 結果として生成される。つぎに時代T'における景観 (C) は, 景観（B）と社会との相互作用の結果として生成されるものとし て設定した。

上記プロセスのもとで生成された景観（B）が『文化的景観』 の要件を満たすためには, 景観 (B) から景観 (A) が辿れる（解 釈できる）ことが重要である。そのためには，景観（A）に対す る社会の関与を把握することで景観（B）から景観 (A) に至る 過程を解釈できることが必要である。そのことによって, 景観 (B) は, 『文化的景観』の要件を満たせるものと考えられる。一方, 景 観（A）に対する社会の関与が把握できない場合，景観（B）か ら景観 (A) を辿る (解釈する) ことが困難であるため, 景観 (B) は, 『文化的景観』の要件を満たせないと考えられる。また, 時代 T'における景観（C）についても同様のプロセスにより『文化 的景観』の要件を満たす否かの判断ができると考えられる。

以上から, 土地履歷から『文化的景観』に承認される妥当性を 有する景観とは, 上記の手続きにもとづき, 景観 (C) から景観 （B）を，景観（B）から景観（A）を辿れる（解釈できる）景 観といえる。

上記に示した『文化的景観』の要件を満たすためには，ある一 定の時間にわたる景観の変化と変化の主要な要因といえる社会の

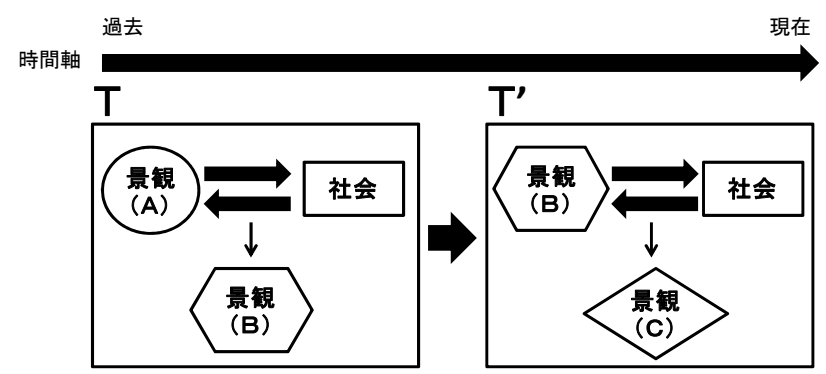

図一2 土地履歴にもとづく『文化的景観』の概念図 (景観 $(A) \cdot$ 景観 $(B) \cdot$ 景観 $(C)$ は同一地点の景観を表している) 
関与を把握できることが必要である。そうした要件を満たすため には，対象とする時間を設定でき，かつ景観の変化・変化の要因 である社会の関与を把握できる史料の所在が重要である。こうし た課題を解決する史料としては，通常，地図と文書（例 : 地方自 治体史等) が用いられることが多く20)，本論文でも上記の史料の 活用を想定する。史料の所在により景観は 4 タイプ，すなわち，

（1）地図: 有 - 文書: 有，（2）地図: 有 - 文書: 無，(3) 地 図: 無・文書: 有，(4) 地図: 無・文書: 無タイプに大別される。

重要文化的景観区域の設定方法にもとづくと, これら4タイプ のうち『文化的景観』に承認される可能性が高いタイプは, 保全 計画の策定に必要な資料の所在によって，判断できると考えられ る 21)22)。才なわち，第 1 には保全区域が画定されることが望まし (21)22)。第 2 には，保全の正当性を担保する根拠として景観の変 化と変化の要因である社会の関与が明確に示されることが望まし (21)22)。これら二つの要件を満たすためには，保全区域の画定と 景観の変化の根拠史料となる地図と，社会の関与の根拠史料とな る文書双方があることが望ましい。そうした観点に立った場合， （1）地図: 有・文書: 有タイプは, 保全の正当性を確保できる ことから，もっとも『文化的景観』に承認される可能性を持つと 考えられる。

こうした考えにもとづき『文化的景観』に承認される景観を特 定した場合には，どのような景観が『文化的景観』に承認される 対象となるのだろうか。次節では，本概念の検証を試みたい。

\section{（2）『文化的景観』に承認される景観を特定する概念の適用}

\section{1）対象とする景観の設定}

本論文が対象とする景観は，江戸時代に，軍馬育成のために設 置した放牧場である牧に関わる景観である。具体的には，千葉県 柏市・鎌ヶ谷市にある中野牧跡および外側に位置する集落と，千 葉県流山市にある上野牧跡の外側に位置する集落に関わる景観を 取り上げる。中野牧・上野牧は，江戸時代に幕府直轄の牧場であ る小金牧の一部として設置された ${ }^{23)}$ 。しかし，江戸幕府の財政政 策，明治政府への政権交代により，牧は払い下げ・上地が繰り返 し行われ，新田開発用地に転用され 23)，戦後は，高度経済成長に 伴う住宅地開発用地として転用された ${ }^{23)}$ 。当該地域は，景観変化 が著しい点において 24)，本論文が提示した概念を検証する事例と して，適切と考えられた。当該地域には，牧に関連する景観要素 として, 馬の流出防止のため造営された史跡捕込・野馬土手があ るが，本論文の目的（『文化的景観』の特定）に合致しないため， 対象に含めない。なお概念の実証にあたっては，主として，宮本 ら 25)の成果を用いた。

2）対象とする期間の設定

当該地域の牧は，江戸時代慶長期（1596〜 1614 年）に設置されたとある 23)。そのうち本 論文では，最も古い地図が所在する 1672 年か ら最新の地形図が作成された年次である 2000 年までを把握する期間に設定した ${ }^{23)}$ 。概念を実 証するために, これらの期間を 2 期に区分した。 一い，江戸時代寛文期の 1672 年から旧版地 形図が作成された大正時代末期の 1925 年であ る (図一3のTに該当)。もう一つは，大正時代 末期以降 (1925～2000 年) である (図-3 の T に該当)。『文化的景観』に承認されや打景観 とは, これら 2 期において, 景観変化と社会の 関与が把握できるものとする。

3）用いた史料

把握に用いた史料のうち，地図は 4 つの牧絵 図 (小金牧周辺野絵図 (1672 年), 中野牧・壱 本椚牧・下野牧図（1722 年），小金牧大絵図
（1787～1793 年)，小金牧絵図 (1862 年)）と旧版地形図である。 文書は，地方自治体史である。

4）土地履歴の解釈にもとづく『文化的景観』の特定

4）-1.『文化的景観』に承認されやすい景観

本事例において地図 : 有・文書 : 有タイプは，中野牧跡内に位 置する初富地区 (千葉県鎌ケ谷市) である 25)。同地区を本稿の『文 化的景観』の概念と照合寸ると，景観（A）から（B）への景観 変化は，小金牧周辺野絵図 (1672 年) や旧版地形図 (1925 年) により把握できる (図-3)。1672 年において, 初富地区は, 中 野牧の一部である野馬立場（放牧地）として利用されていること が把握された（景観A）。1925 年においては，農地造成により農 道整備が行われたことが把握された (景観B)。景観 (A) が社会 に対して与えた影響および景観（A）に対する社会の関与は，鎌 ケ谷市史 26$) 27$ から把握できる。すなわち，前者は官有地だった牧 が開墾の機運を醸成させたこと, 後者は東京府開墾局が牧跡を対 象とした農地造成を行ったことである 26)27)。景観（B）から (C) への景観変化は，旧版地形図（1925 年，2000年）から把握でき る (図-3)。1925 年は, 既述のとおりである（景観B）。2000 年は，東京府開墾局による農地造成・農道整備を基盤とした，農 家による果樹栽培と住宅地開発が行われたことが把握された（景 観 C)。景観（B）が社会に対して与えた影響および景観（B）に 対する社会の関与は，鎌ヶ谷市史 26$)$ から把握できる。すなわち, 前者は開墾された土地が生産性を高めるべく農地造成・農道整備 の機運を醸成させたこと，後者は都市近郊農業の発達により梨を 中心とした農業経営が行われる一方, 都心の人口増加を受けての 住宅地開発が行われたことである ${ }^{27)}$ 。以上より, 当該地区は, 地 図および文書を通して景観 (C) から景観 (A)（B）を辿れる（解 釈できる) ため, 既述した著者の解釈にもとづくと『文化的景観』 に承認される可能性を有する景観と考えられる。

4）-2.『文化的景観』に承認しづらい景観

(i) 地図 : 有・文書 : 無タイプ

上記のタイプに該当するのは，中野牧跡内に位置する南増尾地 区（千葉県柏市）である 25)。同地区は，江戸時代の幕府の財政政 策により牧が払い下げられた後，新田開発用地として利用され， 1945 年以降, 中小の民間ディベロッパーによって小規模な住宅地 開発が行われた地区である 25)。同地区における景観変化は，4つ の牧絵図および旧版地形図などにより，把握できる。景観変化に 対する社会の関与は，江戸時代寛文期〜大正時代末期は，柏市史 28)29)により把握できる。しかし，大正時代末期以降は，中小のデ イベロッパーによる住宅地開発を裏付ける記載が柏市史にみられ

\section{過去} 時間軸

T (江戸時代寛文期 大正時代後期(1672年 1925年)) T “(大正時代後期以降 (1925年 2000))

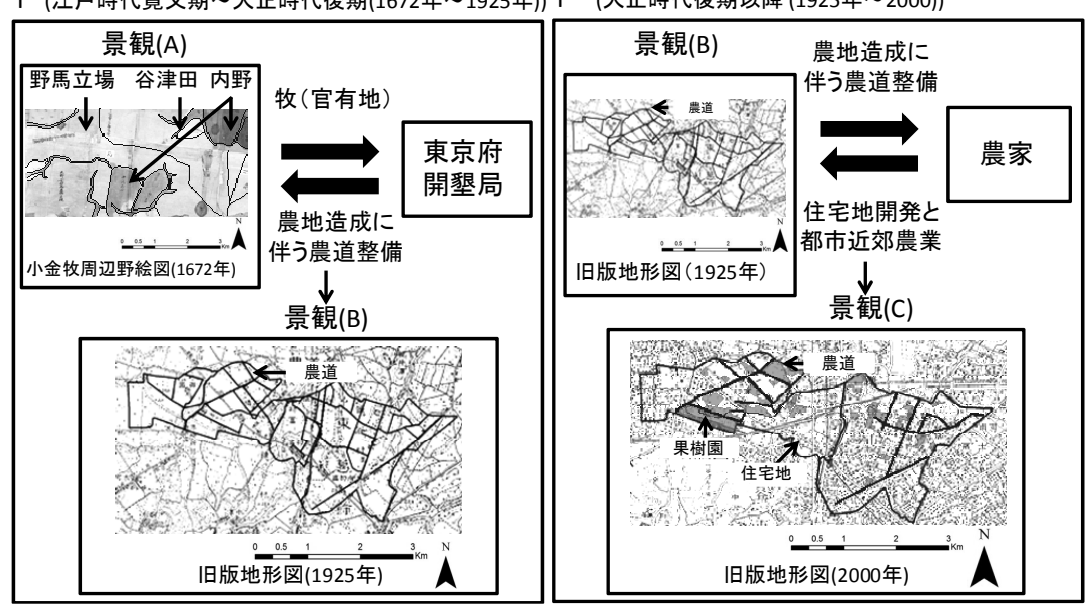

図一3 初富地区における『文化的景観』（1672 年〜2000 年） 
なかった。以上より，同地区は，大正時代末期以降における社会 の関与を裏付ける文書を見出せなかったことから，『文化的景観』 に承認しづらいタイプと考えられる。

(ii) 地図 : 無・文書 : 有タイプ

上記のタイプに該当するのは，上野牧跡の外側に位置する少数 の集落である。ここでは，芝崎地区(現千葉県流山市) を取り上 げる。同地区は，江戸時代，牧の馬を管理していた集落であり， 1973 年に市街化調整区域に指定されたことにより, その後の住宅 地開発が抑制された地区である。同地区は，牧の外側に位置して いたため 4 つの牧絵図に記載されていない。そのため江戸時代寛 文期〜大正時代末期の景観変化が把握できない。景観変化に対す る社会の関与について, 江戸時代享和期〜大正時代末期（1802〜 1925 年) は流山市史に記載される芝崎村統括者が作成した一連の 日記 30-32)，大正時代（1925 年〜）は流山市史 ${ }^{33}$ により把握で きる。以上より，同地区は，江戸時代寛文期〜大正時代末期の景 観変化を把握できないため, 『文化的景観』に承認しづらいタイプ と考えられる。

(iii）地図 : 無・文書 : 無タイプ

本事例において上記のタイプに該当するのは，中野牧跡の外側 に位置する集落である。ここでは, 中沢地区 (現千葉県鎌ケ谷市) を取り上げる。同地区は，江戸時代に牧場を採草地として利用し ていた集落であり, 1970 年に市街化調整区域に指定されたことか ら，その後の住宅地開発が抑制された地区である。同地区は，前 項の事例と同様に，牧の外側に位置していたため 4 つの牧絵図に 記載されていない。そのため江戸時代寛文期〜大正時代末期の景 観変化が把握できない。景観変化に対する社会の関与について, 江戸時代宽文期〜大正時代末期にかけては，同地区が牧を管理す る立場になかったため，鎌ヶ谷市史への記載が少なく，把握が困 難である。ただし大正時代以降は，鎌ヶ谷市史に比較的多くの記 載がみられ，把握できる。以上より，同地区は，江戸時代寛文期 〜大正時代末期にかけての景観変化と社会の関与が把握できない ことから，『文化的景観』に承認しづらいタイプと考えられる。

\section{4. 結論}

\section{（1）CLの成立に影響を与えた言説の整理}

文化庁が文化的景観の概念を検討した際に参考にした世界遺産 条約の登録カテゴリーのCLに関わる 4 つのカテゴリーは，それ までの文化的景観に係る学術的定義を参考にして, 設定・追加さ れたことが把握された。4つのカテゴリーのうち「継続する景観」 は, Wagner \& Mikesell の “文化的景観” の定義 16)に対応するこ とが考察された。同定義は，景観と社会との相互関係から文化的 景観が生成されるとする点において明確な概念が示されており, 『文化的景観』に承認される景観を特定する概念を考える上で, 注目すべき概念であると考えられた。

\section{（2）『文化的景観』に承認される景観を特定する概念の検討}

過去から現在にわたる景観と社会の相互作用を土地履歴と定義 し，設定された期間内における相互作用の過程を解勫できる景観 が『文化的景観』に承認される可能性を有するとの概念を設定し た。

そして解釈に用いる史料である地図と文書（地方自治体史）の 所在により，景観を 4 タイプ ((1) 地図 : 有・文書 : 有, (2) 地図: 有・文書: 無, (3) 地図: 無-文書: 有, (4) 地図 : 無・ 文書 : 無) に分類した。これら 4 タイプのうち（1）地図 : 有・ 文書 : 有タイプは, 『文化的景観』の計画策定に必要な情報（計画 区域の範囲と，保全の正当性を解釈寸る景観変化と，社会の関与 に関わる史料）をすべて有するため，もつとも『文化的景観』に 承認される可能性を持つと判断した。そして本概念を，千葉県柏 市・鎌ヶ谷市、流山市にある中野牧・上野牧跡とその周辺の景観
に適用した。

本研究の捉え方は, 概念を構築した段階にある。様々な景観に 適用できる汎用性を有する方法論の構築に向けては, 多くの課題 が残されている。たとえば，史料の所在を探索する時期の設定方 法などである。こうした点等に配慮した『文化的景観』に承認さ れる景観を特定する方法論の検討は，今後の課題としたい。

\section{補注および引用文献}

1) UNESCO (2008): Operational guidelines for the implementation of the world heritage convention: World heritage centre, 163pp

2) 文化財保護法研究会 (2006) : 最新改正文化財保護法 : ぎょうせい，1-74

3）文化庁文化財部記念課（2005）：日本の文化的景観，農林水産業に関連する文化 的景観の保護に関する調查研究報告書 : 同成社, $323 \mathrm{pp}$

4）文化庁文化財部記念物課（2010）: 都市の文化と景観，採掘・製造，流通・往来 及び居住に関連する文化的景観の保護に関寸る調查研究会編 : 同成社, $203 \mathrm{pp}$

5）歷史まちづくり法研究会 (2009) :歴史まちづくり法ハンドブック:ぎょうせい， 286pp

6）前掲書 3), $40-50$

7）横張真・渡部陽介 (2009)：農山村における文化的景観の動態保全，ランドスク 一プ研究，73(1)，10-13

8）前掲書 3)，p18，によると，「重要地域の選択の基淮は，I．農山漁村地域に固 有の伝統的産業及び生活と密接に関わり, 独特の土地利用の典型的な形態を顕著 に示寸もの，II. 農山漁村地域の歴史及び文化と密接に関わり，固有の風士的特 色を顕著に示寸もの, III. 農林水産業の伝統的産業及び生活を示寸単独又は一群 の文化財の周辺に展開し，それらと不可分の一体的価值を構成するもの，IV．Ｉ 〜IIIが複合することにより, 地域的特色を顕著に示寸もの」とされているが, i)ii 以外の景観に関する選定基淮については言及されていない。

9）前掲書 3)，p63，によると，「文化的景観という概念を育てていく姿勢をとる必 要がある」「学術的価值が高いものに限らず柔軟に定義する必要がある」という 議論がなされている。

10) Fowler P. J. (2003): World heritage cultural landscapes 1992-2002: World heritage centre, $140 \mathrm{pp}$

11) UNESCO (1992): Report of the expert group on cultural landscapes, La Petit Pierre (France), 24-26 October, 1992, 1-6

12) 前掲書 3$), \mathrm{p} 5$

13）前掲書 3$)$, p57

14）平澤毅 (2005) : 遺産の保護と文化的景観 : 都市計画 54(1), 15-18

15) Sauer C. O. (1925): The morphology of landscape: University of California Publication in Geography, Vol.2.2, 19-53

16) Wagner L.P. \& Miksell W.M. (eds) (1962): Readings cultural geography: University of Chicago Press, 589pp

17) Munjeri D. (2000): Cultural landscapes in Africa, Rossler and saouma-forero, $35-43$

18) Melnick R.Z. (1984): Cultural landscape: Rural historic districts in the national park system, Washington D.C.: U.S. Department of the interior, National park system, 80pp

19）井手久登（1975）: 景観の概念と計画，都市計画 83 (特集景観論)，日本都市計 画学会, $10-13$

20）有薗正一郎・遠藤王俊・小野寺淳・古田悦造・溝口常俊・吉田敏弘 (2001) : 歴 史地理学の方法と課題, 歴史地理調査ハンドブック，古今書院， 1-16

21）文化庁: 魅力ある風景を未来一一文化的景観の保護制度, p7

22）前掲書 5)，71-102

23）宮本万理子・横張真 (2010)：下総台地における牧の払い下げと近代化以降の土 地利用の変遷 : ランドスケープ研究 73(5), 631-636

24）横張真 (2005) : 郊外の緑地景観をめぐる恒久性と可塑性 : 建築学会総合論文誌 (3), $61-63$

25）宮本万理子・横張真・保科宇秀 (2011) : 牧の执い下げ形式にもとづく下総台地 における景観の特徴解明 : ランドスケープ研究 74（5)，673-678

26）鎌ヶ谷市 (1991）: 小金牧 : 鎌ヶ谷市教育委員会「鎌ヶ谷市史中巻」：弘文社, 589-649

27）鎌ヶ谷市 $(2002 ）$ : 鎌ヶ谷のあゆみ，総合印刷新報社，310pp

28）柏市（1995）：小金牧の設置と農民の夫役 : 柏市教育委員会「柏市史近世偏」 ぎょうせい，411-467

29）柏市（2000）: 牧の廃止と開墾の実現 : 柏市編纂委員会「柏市史近代偏」：ぎょ うせい, 163-268

30）流山市 (1992)：流山市史近世資料編III : 流山市教育委員会，703pp

31）流山市 (1993) : 流山市史近世資料編IV : 流山市教育委員会, 812pp

32）流山市 (1994) : 流山市史近世資料編V : 流山市教育委員会, 954pp

33）流山市 (2005)：流山市史通史編II：流山市教育委員会，938pp 